\title{
HABITAÇÃO, CIDADE E MODOS DE MORAR. A transformação do padrão COHAB a partir da iniciativa dos usuários.
}

\author{
HOUSING, CITY AND WAYS OF LIVING. \\ The transformation of the COHAB pattern after the users' initiative.
}

\author{
A. Liziane de Oliveira Jorge \\ Departamento de Arquitetura e Urbanismo; Universidade Federal do Espírito Santo, Brasil \\ lizianej@gmail.com
}

\section{B. $\quad$ Nirce Saffer Medvedovski \& C. Gustavo Benedetti Santiano}

Faculdade de Arquitetura e Urbanismo; Universidade Federal de Pelotas, Brasil nirce.sul@gmail.com

gustavobenedetti97@gmail.com

\begin{abstract}
RESUMO
O presente trabalho investiga o processo de transformação do Conjunto Habitacional Lindóia, localizado no município de Pelotas/RS, com ênfase nas estratégias de crescimento e adaptação das unidades residenciais populares planejadas através de intervenções de seus moradores. Expoente representativo da política habitacional do país orientada para a população de baixa renda, o Conjunto de cunho modernista consolidou um grande complexo residencial de casas em fita sobrepostas nos moldes da habitação mínima, abrigando famílias de arranjos plurais em unidades tipificadas. A investigação das transformações foi orientada à luz de técnicas de Avaliação Pós-Ocupação, com trabalho de campo, interlocução com moradores e registro gráfico completo das etapas de intervenção em unidades transformadas. O trabalho identifica, a partir da documentação das unidades, as estratégias construtivas empregadas e a relação destas com as necessidades e anseios dos distintos grupos familiares. Sinaliza a necessidade de acompanhamento profissional ou assessoria técnica para impulsionar a qualidade da habitação.
\end{abstract}

Palavras-chave: habitação, Avaliação Pós-Ocupação, COHAB, habitação evolutiva.

Linha de Investigação: 1. Cidade e projeto.

Tópico: Habitação e projeto residencial.

\section{ABSTRACT}

The present work researches the transformation process of the Lindoia Housing Complex (COHAB Lindoia), located in the city of Pelotas/RS, Brazil, with emphasis on the growing and adaptation strategies of the social interesting residential unities planned through intervention of their residents. Representative exponent of the country's housing politics oriented for the low-income population, the Complex, of modernist nature, 


\section{SÃO PAULO15 17 LISBOA $25 \sim 26$ JUN 2020}

consolidated a big housing complex of superimposed row houses on the molds of minimum dwelling, sheltering families of plural arrangements in typified unities. The investigation of the transformations was oriented in light of Post-Occupancy Evaluation techniques, with field work, interlocution with residents, and complete graphic record of the intervention phases in transformed unities. The work identifies, from the documentation of the unities, the constructive strategies used and the relation of those with the necessities and yearnings of the distinct family groups. The article signals the need for professional or technical support to promote housing quality.

Keywords: housing, Post-Occupancy Evaluation, COHAB, evolutive housing.

Research line: 1 . City and project.

Topic: housing and housing project.

\section{Introdução}

O presente trabalho investiga o processo de transformação do Conjunto Habitacional Lindóia, localizado no município de Pelotas/RS, com ênfase nas estratégias de crescimento e adaptação das unidades residenciais populares planejadas através de intervenções de seus moradores. Materializado no período final de vigência do Banco Nacional de Habitação, quando, ao iniciar o último governo do período da ditadura militar, 1979, a habitação destinada às mais baixas rendas é resgatada como programa prioritário. O Ministério do Interior estipulou a construção de seis milhões de unidades em seis anos. No final do mesmo ano, essas metas tornam-se mais modestas, sendo que, para o Rio Grande do Sul estipulam a construção de 160.000 moradias em quatro anos.

Como uma das formas de viabilização deste plano, as Companhias de Habitação - COHABs deflagraram o que popularmente se denominou "Projeto Pacote", ou seja, o desenvolvimento de um empreendimento habitacional totalmente efetuado na sua fase de produção pela iniciativa privada, da escolha do terreno ao projeto e construção. Coube à $\mathrm{COHAB}$ o estabelecimento de metas, a viabilização da produção através das licitações e a liberação de recursos, bem como o controle do produto e a promoção de sua comercialização. A fórmula encontrada para acelerar a circulação dos recursos considerou passar parte da gestão do processo para a iniciativa privada, de modo que a empresa, responsável pela definição e obtenção do terreno assumiu decisões estratégicas, desde a concepção do projeto, a implantação das unidades habitacionais, a definição do sistema construtivo e dos projetos ditos "complementares". Esses preceitos significaram a participação de empresas dispostas em jogar o jogo com suas novas regras: produção em massa, aumento da produtividade através da incorporação de novos materiais e novas tecnologias.

O município de Pelotas absorveu um crescimento populacional considerável entre as décadas de 1950 e 1980, em decorrência do crescimento vegetativo e nas migrações regionais (VIEIRA, 1997). Os vetores de expansão urbana da cidade que viriam absorver essa demanda situaram-se na periferia, conforme interesses dos latifundiários, dos promotores imobiliários e dos concessionários de serviços públicos, a fim de "patrocinar" uma "ideologia de crescimento". Situados longe do centro urbano, os três grandes conjuntos residenciais produzidos pela COHAB na cidade de Pelotas materializaram um total de 6.000 unidades distribuídas entre consórcios de empresas locais de construção civil, materiais de construção e construção pesada, resultando na promoção de três conjuntos habitacionais: Lindoia, Guabiroba e Pestano (MEDVEDOVSKI, 1998). 


\section{XII $\square$ SÃO PAULO15 17 LISBOA $25 \sim 26$ JUN 2020 \\ Seminário Internacional de \\ Seminario Internacional de Investigação em Urbanismo

\section{A transformação do Conjunto e as suas implicações}

O conjunto habitacional Lindóia, de cunho modernista, foi concebido no início da década de 1980 na forma de um grande complexo residencial, com associação de sete superquadras preenchidas com espaços livres de uso público, vias internas exclusivas de pedestres e vias urbanas de maior porte, com bolsões de estacionamento distribuídos em locais estratégicos em cada superquadra (Figura 1). A unidades residenciais, do tipo casa em fita sobreposta, estão implantadas sobre as quadras internas, com recuos frontal de ajardinamento e de fundos de cinco metros. Cada superquadra abriga em seu interior espaços públicos constituídos por praças equipadas com mobiliário urbano e equipamentos infantis e de lazer. Uma superquadra localizada bem ao centro do complexo destina-se exclusivamente aos equipamentos públicos e comunitários, definindo a polarização e a centralidade do conjunto.

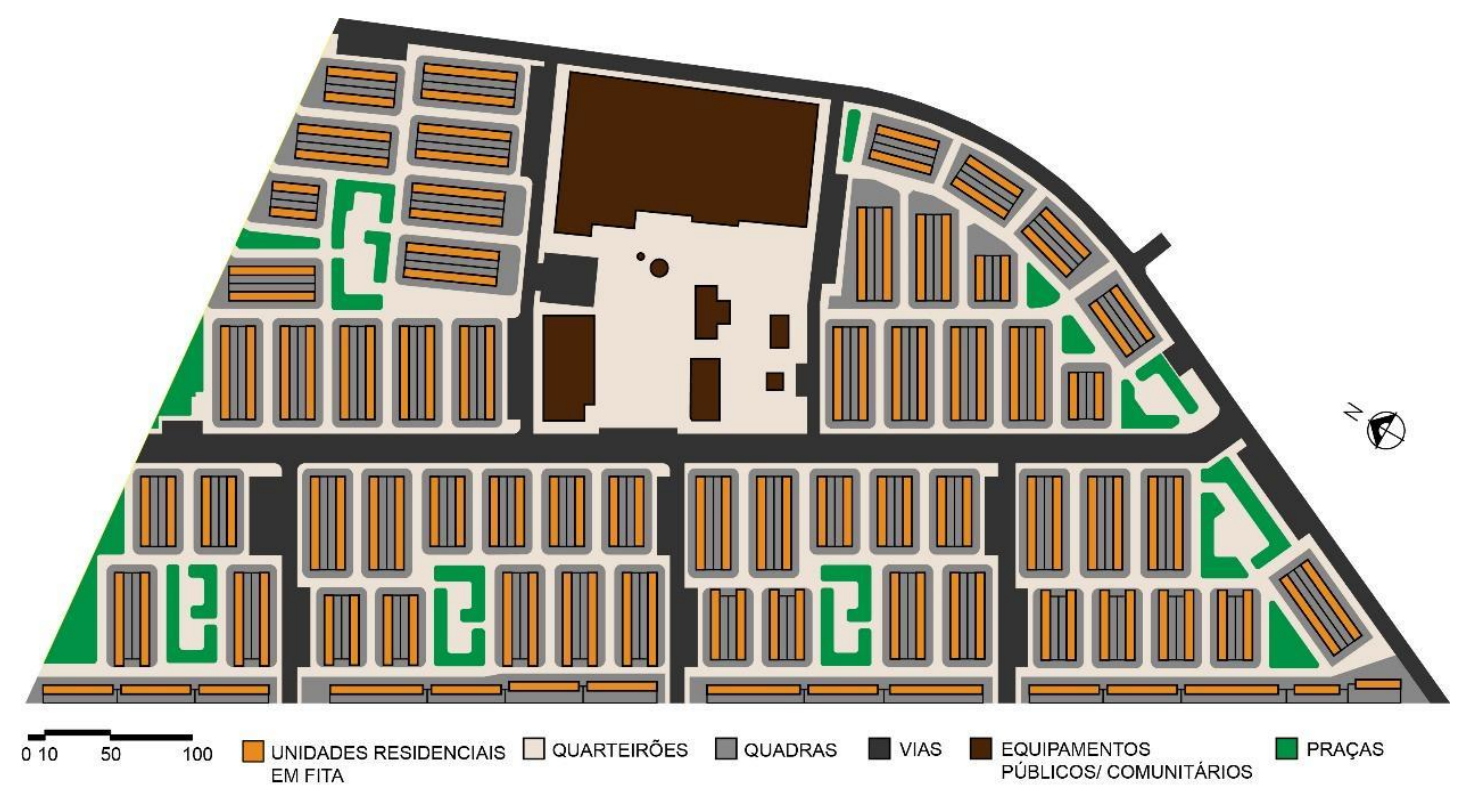

Fig. 1 - Implantação do Conjunto Habitacional Lindóia. Fonte: Dos autores, 2018.

A tipologia residencial, em configuração casa em fita sobreposta, é composta por 1788 unidades combinadas de diferentes formas (Figura 2). A variação dimensional dos apartamentos oscila entre 29 a $40 \mathrm{~m}^{2}$, com unidades de 1 dormitório (também denominada quitinete), 2 e 3 dormitórios. Ao todo, são 128 fitas que agrupam de 16 a 32 unidades, originalmente permeáveis pelo corredor central localizado no afastamento de fundos e franjas ajardinadas de 5 metros à frente e lateralmente (Figura 3). A proporção dos tipos evidencia o predomínio de unidades de 2 dormitórios (60\%), 1 dormitório (25\%) e apenas $15 \%$ de 3 dormitórios. O projeto significou a produção de milhares de unidades tipificadas à luz de preceitos emblemáticos à época: funcionalidade, economia, racionalidade, habitação mínima, padronização. 


\section{SÃO PAULO 15 $\sim 17 \cdot$ LISBOA $25 \sim 26$ JUN 2020 \\ Seminário Internacional de \\ Seminario Internacional de Investigação em Urbanismo Investigación en Urbanismo}

\section{Esquema das Fitas e Tipologias das Casas}

Esquema 3-1/1-3/1-1

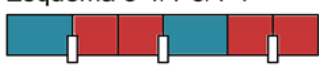

Esquema 3-1/1-3/3-1/1-1

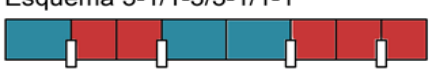

Esquema 3-1/1-3

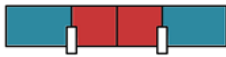

Esquema $2-2 / 2-2 / 2-2 / 2-2$

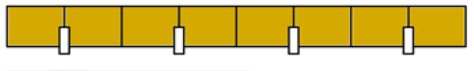

Modelos de quadras
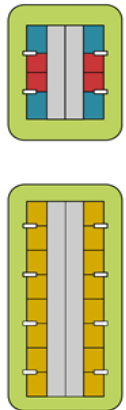

$\overline{05 \overline{10 \quad 20 m}}$

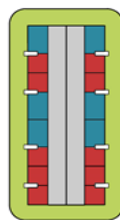

Exemplo de Unidade 3-1

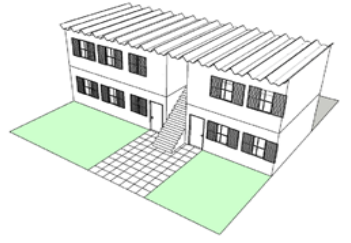

\begin{tabular}{|r|}
\hline Unidade de 1 Dormitório $\square$ \\
Unidade de 2 Dormitórios $\square$ \\
Unidade de 3 Dormitórios $\square$ \\
Caixa de Escada $\square$ \\
Pátio Frontal $\square$ \\
Pátio de Fundos $\square$ \\
\hline
\end{tabular}

Fig. 2 - Esquema das fitas e tipologia das unidades residenciais. Fonte: Dos autores, 2018.

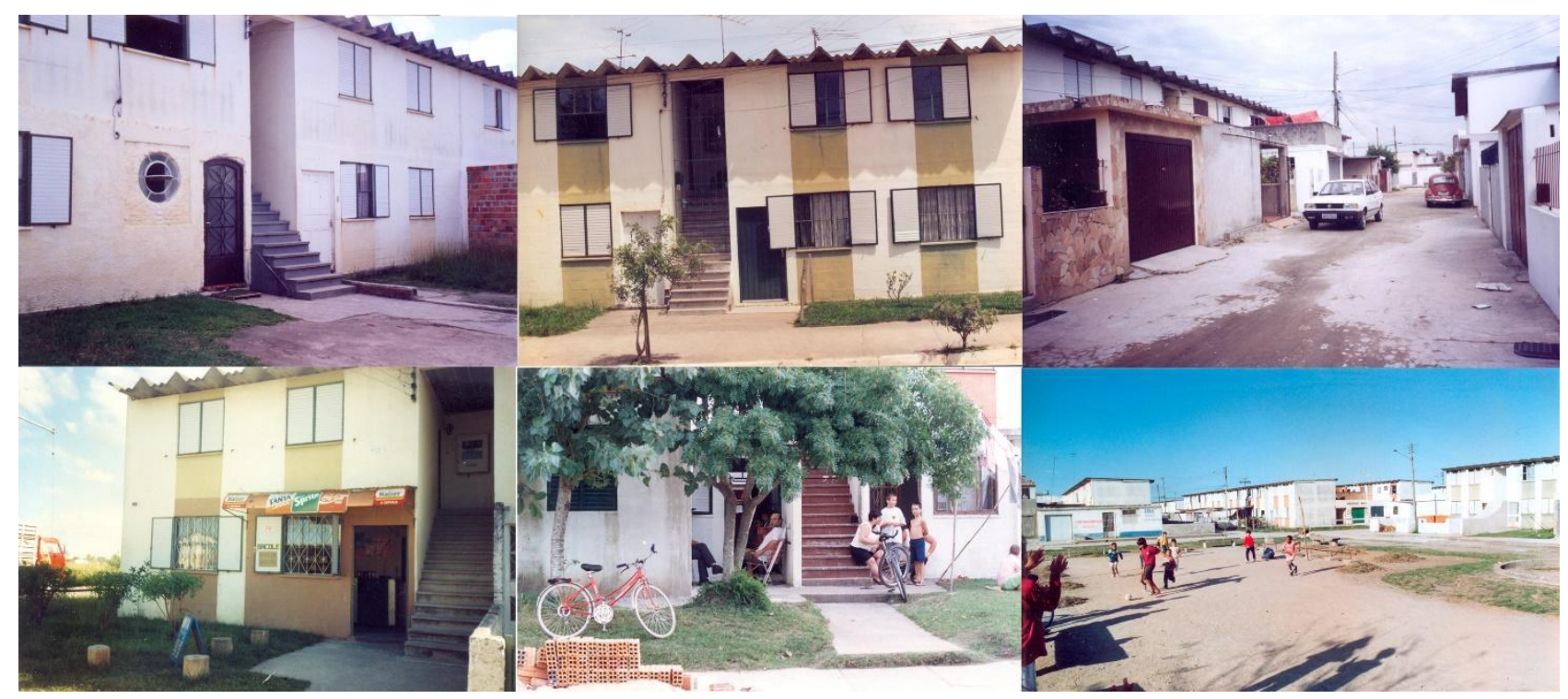

Fig. 3 - Fotos do Conjunto Habitacional Lindóia na década de 1990, com poucas modificações. Fonte: Medvedovski, 1998.

Este trabalho apresenta resultados parciais do Projeto de Extensão atrelado à pesquisa intitulado "Aprendendo com o usuário. Estratégias de transformação no espaço habitacional", possibilitando a troca de conhecimentos entre alunos e moradores, com oportunidade aos alunos de conhecer as alternativas projetuais construtivas empregadas pelos usuários para solucionar o problema do espaço residencial de dimensões reduzidas ou dimensionado em desacordo com as necessidades de cada família. Os moradores, por sua vez, recebem o retorno do projeto na forma de prestação de serviços, com o recebimento do conjunto de informações técnicas de sua unidade, plantas de regularização da obra realizada e desenhos arquitetônicos complementares em meio analógico e digital, bem como assessoria em caso de alguma necessidade de modificação. Essas iniciativas espontâneas de reforma são resposta autóctones ao projeto 


\section{SÃOPAULO15 17 LISBOA $25 \sim 26$ JUN 2020

padrão, que, conforme alerta GARCÍA-HUIDOBRO, TORRITI E TUGAS (2008), muitas vezes não atende às reais demandas das famílias, o que motiva ações de ampliação da edificação, realizada pelos próprios moradores e suas redes.

Esse cenário representa um universo amplo de investigação, recorrente no cotidiano de muitas famílias brasileiras, diante da conjuntura econômica que impõe um padrão enxuto de moradia. Nesse sentido, verifica-se, inclusive a inserção de atividades anexas ao espaço da unidade, como solução para a ausência de atividades comerciais e geradoras de renda no empreendimento, que possui quase 1788 unidades. BENETTI (2012) assinala a evolutividade como uma prática construtiva oportuna para promover a economia popular e a renda. Complementarmente, o uso misto é uma estratégia consagrada para qualificação dos lugares, considerando o conceito de urbanidade, descrito por AGUIAR e NETTO (2012) enquanto civilidade de convívio, reforçada pela capacidade de trocas urbana, atividades e socialização. MEDVEDOVSKI (1998) identifica a possibilidade do conjunto monofuncional, promovido nos finais do período do Banco Nacional da Habitação, transformar-se efetivamente num bairro ao incorporar atividades de comércio e serviços e permanecer aberto às comunidades de seu entorno.

Em um contexto contemporâneo, o Complexo, após quase quatro décadas, apresenta-se substancialmente transformado pelos moradores, e as unidades residenciais acresceram novos usos e compartimentos que ressignificaram o espaço de moradia e a vida urbana do lugar. A hipótese de adequação da unidade aos novos modos de vida, aos perfis familiares plurais e às preferências individuais e necessidades produtivas é a premissa que motivou a investigação desse fenômeno nas unidades residenciais da COHAB Lindóia. À medida que as transformações no espaço físico se consolidavam, as relações do conjunto com a cidade foram progressivamente alteradas, rompendo as feições de uniformidade da paisagem, bem como as vivências e trocas sociais imediatas presentes na morfologia original, concebida sem recuos privados ou espaços externos de uso coletivo.

As transformações morfológicas consumadas pelos moradores no Conjunto alteraram profundamente múltiplos aspectos da morfologia urbana: as fachadas foram remodeladas em decorrência de preenchimentos e adições construtivas para acomodar garagens, varandas, sacadas, novos cômodos privativos, atividades comerciais, acréscimos verticais; o padrão fundiário foi modificado através do consumo dos recuos de ajardinamento, originalmente coletivos, interrompendo a permeabilidade das quadras e alterando relações de convívio que outrora se estabeleciam livremente no afastamento frontal; as vias internas exclusivas voltadas para a mobilidade pedonal foram adulteradas para fazer passar modais de transporte individual; dispositivos de proteção vertical, muros e grades dispostos no alinhamento romperam os vínculos de vizinhança impostos pelo projeto original; atividades produtivas foram incorporadas a partir do consumo de recuos frontais e anexos em fachadas cegas; modernizações estéticas e personalização da fachada frontal conferem novo significado e identidade ao bairro.

A esse respeito, uma breve análise da imagem aérea da COHAB Lindóia é capaz de evidenciar o grau de modificação do Conjunto ao longo de muitas décadas. A imagem aérea de uma única superquadra do Conjunto (Figura 4), demonstra a intensidade das adições em todo o empreendimento. É possível perceber as fitas originais das residências, marcadas pela linearidade das telhas de tipo fibrocimento que recobrem o telhado das unidades superiores, hoje marcado pelo tempo em uma coloração cinza-escuro. Adjacente a essas linhas, tanto nos fundos quanto em torno do perímetro de todas as quadras internas, notam-se as 


\section{SÃO PAULO15 17 LISBOA $25 \sim 26$ JUN 2020 \\ Seminário Internacional de \\ Seminario Internacional de Investigação em Urbanismo Investigación en Urbanismo}

adições: um grande mosaico de novos cômodos de diferentes telhados e revestimentos, com fachadas frontais separadas apenas pelas estreitas vias de pedestres substituem o que originalmente consistia grandes pátios vegetados.

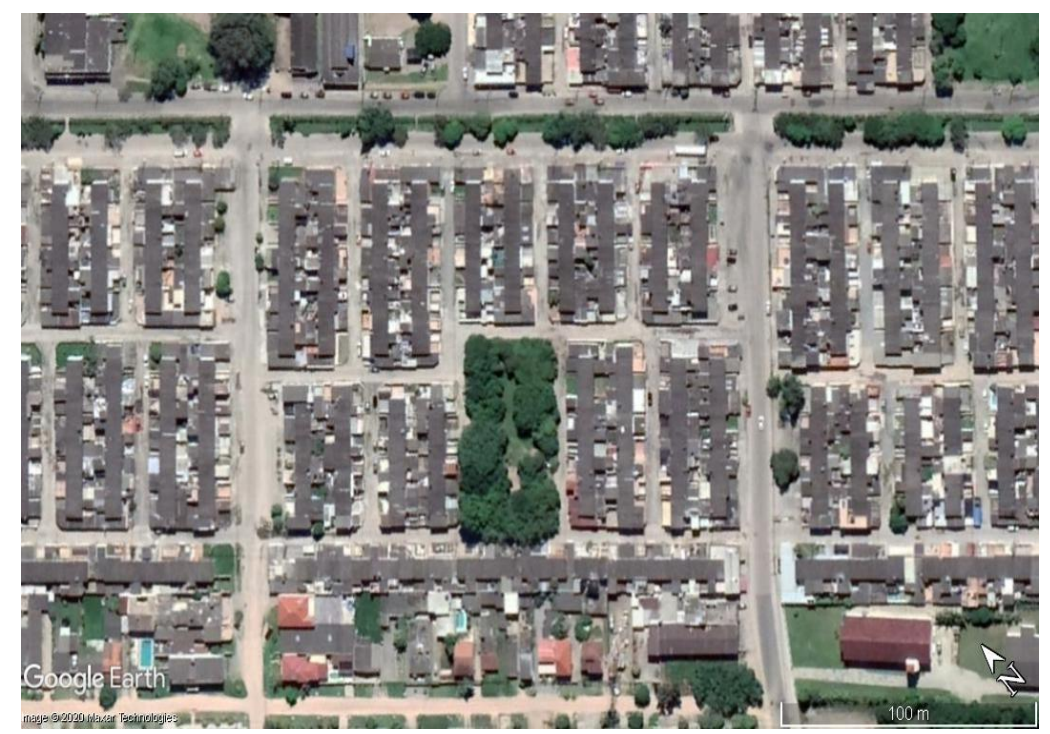

Fig. 4 - Imagem aérea de uma superquadra do Conjunto. Fonte: Google Earth Pro, 2020.

Vale destacar que a gestão em forma de condomínio nunca foi instituída, e as generosas áreas condominiais, usualmente reconhecidas como espaços coletivos e permeáveis, foram as que abrigaram as alterações mencionadas. É importante também relatar a modificação operada no perfil e número de moradores do conjunto habitacional ao longo de sua história. Entregue em 1982, o censo populacional de 1990 identificou 5.180 habitantes, ocupando as 1788 unidades habitacionais originais. Em 2010 (IBGE, 2010) o número passa para 4.056 com uma diminuição de $19,8 \%$ no número de pessoas ao longo de 20 anos (BARBOSA et. al., 2018, p. 548), passando de 3,14 para 2,45 habitantes por domicílio. A população também envelheceu e apresenta em 2010 um perfil etário bastante diverso da média da cidade, com uma concentração na população de 50 a 54 a anos, aumento da população com mais de 60 anos (equivalente a 9,58\% dos moradores), predomínio de mulheres (57\%) e a verticalização da pirâmide etária. Pelotas, apesar da diminuição da base da pirâmide, tem sua maior concentração entre 20 a 30 anos.

\section{Procedimentos Metodológicos}

A metodologia do trabalho compreende uma imersão no espaço doméstico das famílias, com aplicação inicial de técnicas distintas de Avaliação Pós-Ocupação: Questionário, Entrevista Estruturada, Walkthrough, Levantamento físico da casa e do lote, Registro fotográfico dos espaços interiores e exteriores. Cada etapa objetiva escrutinar as modificações na morfologia do espaço construído e identificar as estratégias recorrentes empregadas pelos moradores, correlacionando as alterações construtivas aos distintos estágios do perfil familiar dos residentes. Os métodos empregados envolvem análises em distintas escalas: na escala do bairro, pressupõe a identificação precisa das intervenções que se refletem nas fachadas e, 


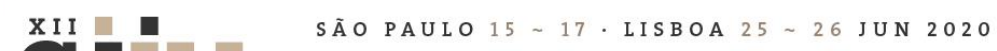

consequentemente, nos espaços públicos. Na escala das unidades residenciais, o trabalho abarca uma amostra de dez casas representativas do bairro.

O ponto de partida para o desenvolvimento do trabalho foi a reunião da documentação técnica de todo o Complexo Habitacional, considerando as etapas do projeto arquitetônico executado e os projetos complementares na escala urbana, como drenagem, iluminação, implantação e outros. O segundo passo, referente à escala do bairro, envolveu o diagnóstico urbanístico, acompanhado de diagramas de análise urbana (usos do solo, espaços livres, fluxos, mobilidade urbana, gabarito, paisagem, etc.) e do registro fotográfico.

O levantamento de campo se deu em etapas sucessivas: a primeira com o objetivo de identificar a natureza das atividades comerciais implementadas no complexo, originalmente monofuncional, e a segunda com ênfase nas unidades residenciais e na sua transformação ao longo do tempo. O levantamento das unidades, objeto específico deste artigo, compreendeu o registro fotográfico do espaço externo e interno das unidades, medições da arquitetura e do mobiliário dos residentes, entrevista semiestruturada com o chefe de família, análises gráficas e diagramas destacando as fases das modificações da planta-baixa, identificação de meios técnicos e dispositivos de transformação empregados, e modelagens tridimensionais para evidenciar as alterações e acréscimos (Figuras 5 e 6).
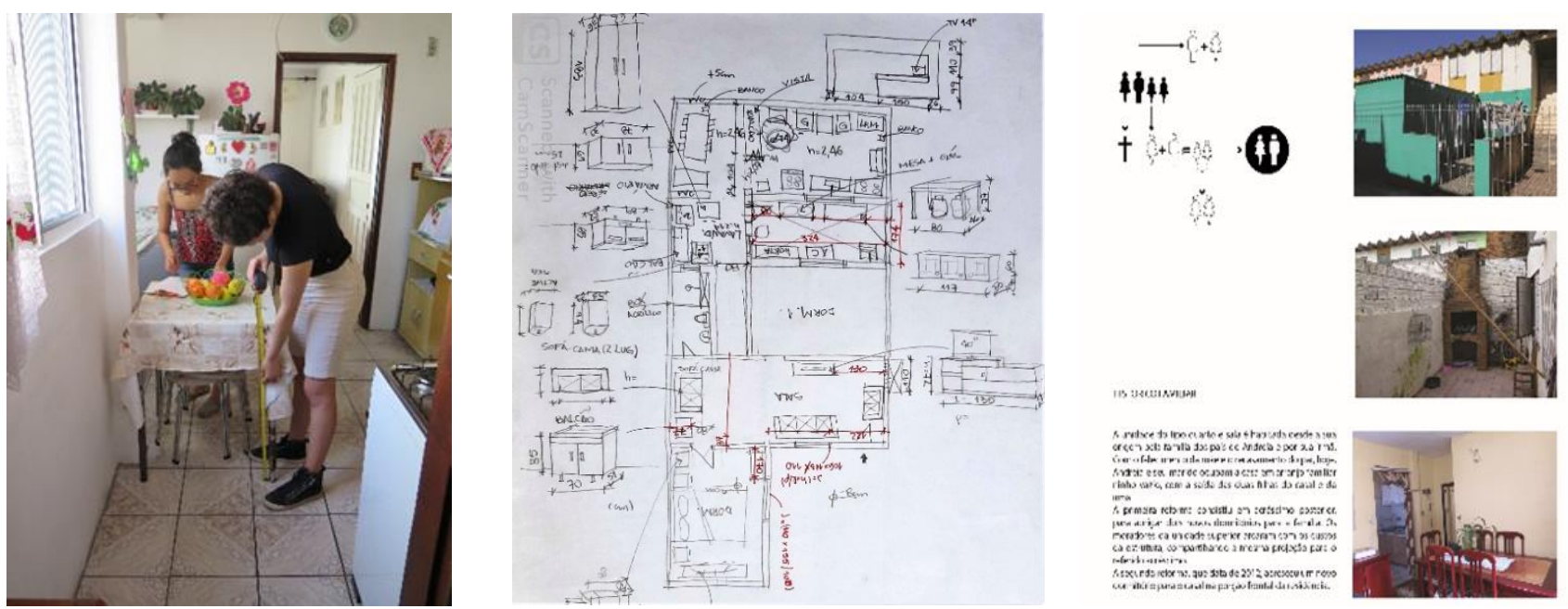

Fig. 5 - Etapas do levantamento de campo das unidades. Fonte: Dos autores, 2018. 


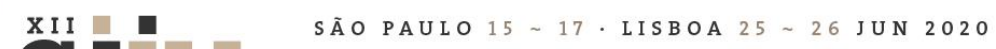

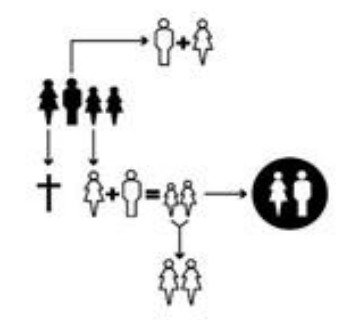

HISTÓRICO FAMILIAR
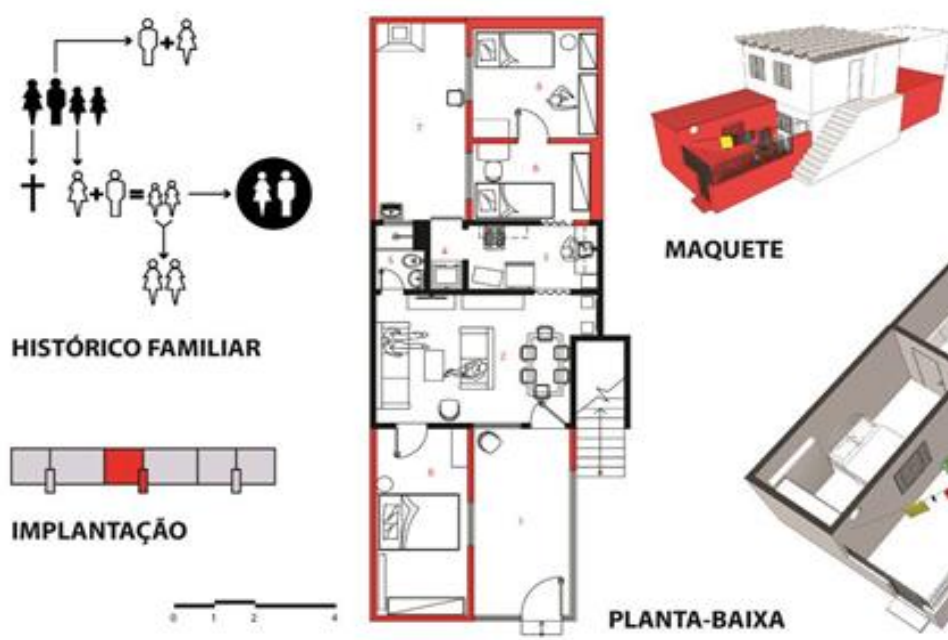

http://dx.doi.org/10.5821/SIIU.9739

Fig. 6 - Produtos gráficos das modificações das unidades e diagramas. Fonte: Dos autores, 2018.

A entrevista semiestruturada foi o essencial para a compreensão apurada da cronologia das reformas consecutivas e da relação com as necessidades da família em casa estágio de seu desenvolvimento. O roteiro de entrevista envolveu o registro dos dados socioeconômicos, ocupação do responsável, renda, caracterização do perfil familiar (em cada estágio), condição da ocupação (se própria ou alugada), tempo de habitação da unidade, relações de vizinhança, modos de deslocamento e transporte. A tipologia envolveu a identificação do tipo de apartamento, quantidade e tipo de reforma, motivação para a reforma, histórico habitacional (relação família $x$ reforma), projeto e execução da reforma, problemas e patologias construtivas antes e após a reforma, acordos com o vizinho para a reforma, satisfação com o imóvel e com a aparência do complexo. Essencialmente, a entrevista permitiu a coleta de depoimentos e narrativas conectadas às transformações efetuadas na habitação em distintos estágios.

Após o levantamento, procedeu-se a etapa de produção gráfica, com redesenho das plantas de reforma (acompanhada dos cortes, fachadas, planta de cobertura e layout com posicionamento de todo o mobiliário do morador), modelagem tridimensional da unidade com demonstração do antes e depois, diagramas das etapas de reforma. Após a fase de levantamento, a equipe retornou para entregar o kit arquitetônico ao morador, contendo as plantas de regularização, as imagens da residência e um caderno personalizado (Figura 7). 


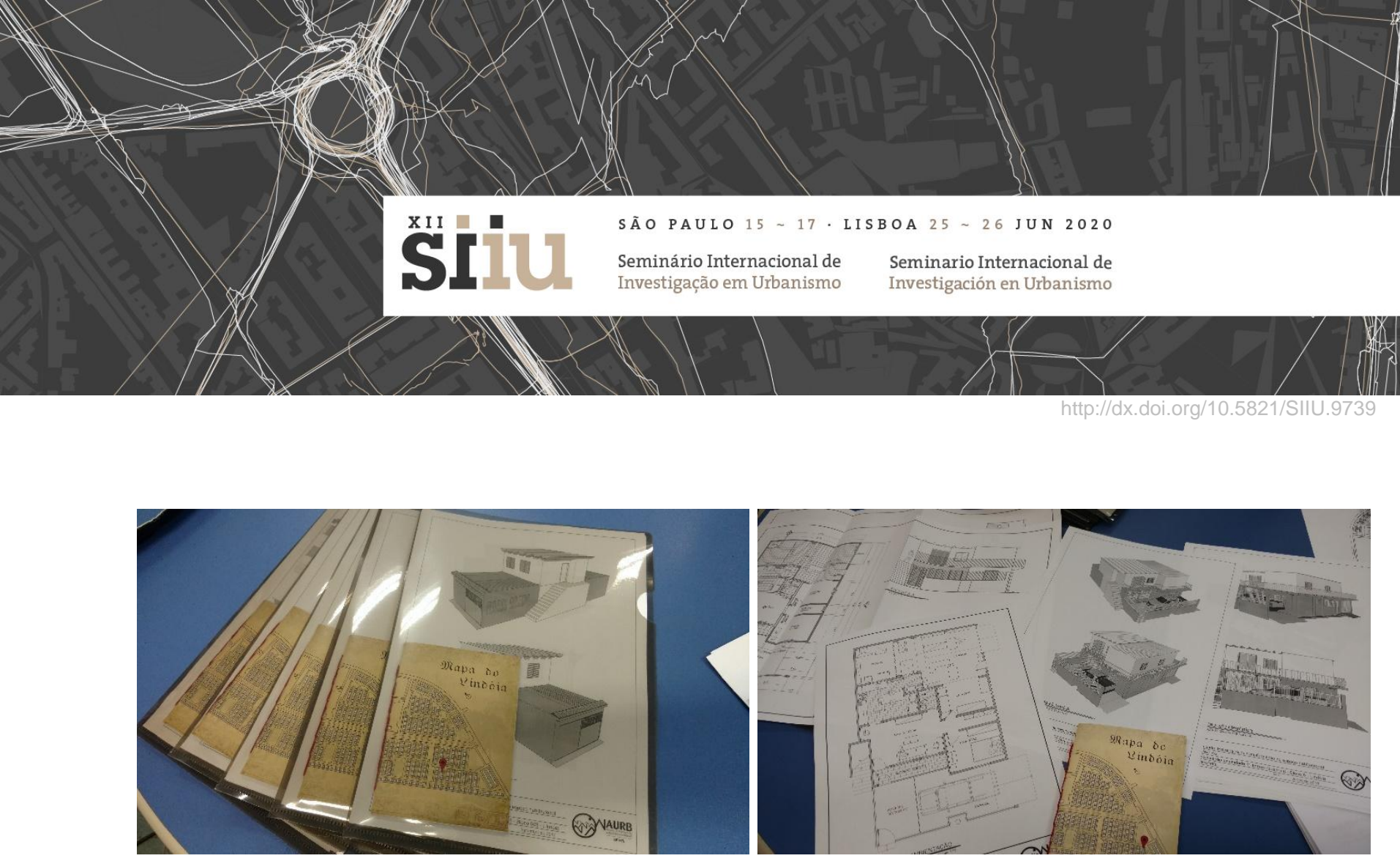

Fig. 7 - Kit para entrega aos moradores. Fonte: Dos autores, 2018.

\section{Resultados e Discussão}

Os casos selecionados para este trabalho reúnem padrões morfológicos de crescimento espontâneo que se relacionam à forma de implantação das unidades na quadra e as demandas de cada família diante das necessidades de uso e modificação dos espaços. De fato, observa-se que os limites das fitas e a sua implantação padrão sofreram modificações substanciais considerando o limite de 5 metros dos recuos frontais e de fundos. Entre os moradores das unidades sobrepostas, a execução de uma estrutura portante em concreto foi determinante para a manifestação de modificações nas unidades superiores. As manifestações relevantes encontradas apontam para o acréscimo de dormitório principal no afastamento frontal, inserção de vaga de garagem coberta no recuo frontal; inclusão de grades de proteção e portões no afastamento frontal e muros de divisa entre as unidades nos fundos; consumo de pátios internos com novos dormitórios, ampliação do espaço da cozinha ou áreas de serviço cobertas. A inserção de atividades produtivas em casas de localização estratégica, em esquina, à frente de espaços públicos ou em vias de maior dimensão, é outro fenômeno observado que se alinha às necessidades do mundo laboral diante da redução de empregos formais e das oportunidades do micro empreendedorismo.

\subsection{Acréscimo de uso comercial: Casa de esquina \& minimercado}

A casa de Claudio e Larissa compreende, originalmente, uma unidade mínima térrea situada em esquina com sala e quarto integrado, distribuídos em $29,6 \mathrm{~m}^{2}$. Situada à frente de uma das praças do complexo, a casa dispõe de localização estratégica e visibilidade privilegiada. Abriga um casal sem filhos, em que a mulher trabalha na área da saúde em expediente integral e o homem atua em atividade comercial adjacente ao espaço privado da residência. A unidade, adquirida já com o acréscimo de dois dormitórios e ampliação da área da cozinha, serviço e garagem coberta, sofreu novo processo de modificação. A mudança de uso da garagem coberta e do pátio de fundos cedeu lugar a uma padaria e um minimercado, atividades comerciais indispensáveis ao cotidiano do bairro. O estabelecimento conta com equipamentos industriais para assar pães, balcão de expositores para hortifruti, prateleiras para produtos do mercado, geladeiras e freezers para bebidas e demais produtos refrigerados, caixa em localização central e espaço de estocagem $O$ estabelecimento ocupou um dos quartos acrescidos e expandiu as suas atividades a partir de reforma recente. O casal encontra-se satisfeito com a residência, com uma cozinha ampliada, com vaga de garagem protegida, alpendre de transição para o espaço social e aproximadamente $50 \mathrm{~m}^{2}$ de espaço dedicado ao comércio. A área total construída após as modificações atinge 110,67m² (Figura 8). 


\section{SÃO PAULO 15 $\sim 17 \cdot$ LISBOA $25 \sim 26$ JUN 2020 \\ Seminário Internacional de Investigação em Urbanismo \\ Seminario Internacional de Investigación en Urbanismo}
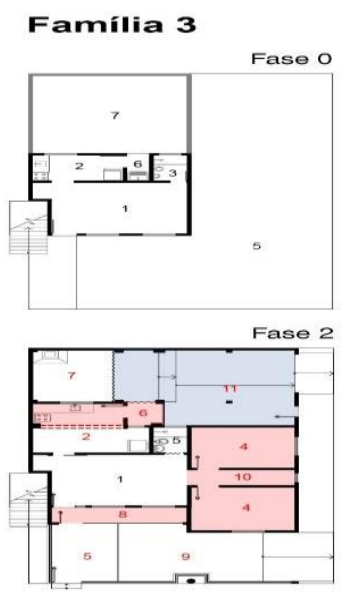

$\widetilde{3 m}$

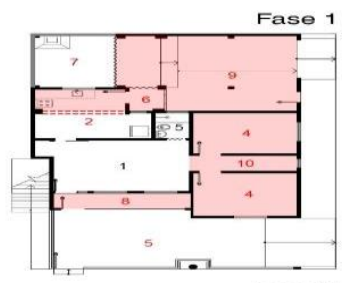

Fase 3

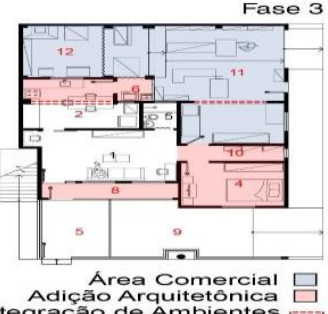

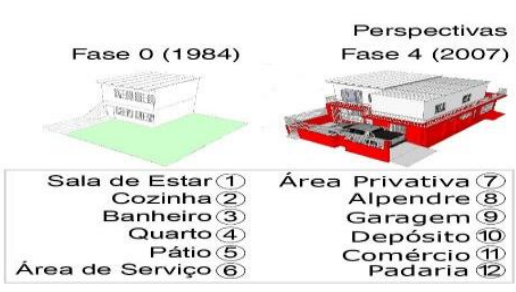

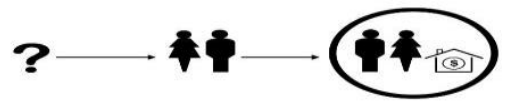

Constituição Familiar Desconhecida? Permanência na Constituição Familiar Constituição Familiar Atual

Fig. 8 - Transformações da casa de esquina. Da casa mínima ao micro empreendedorismo. Fonte: Dos autores, 2018.
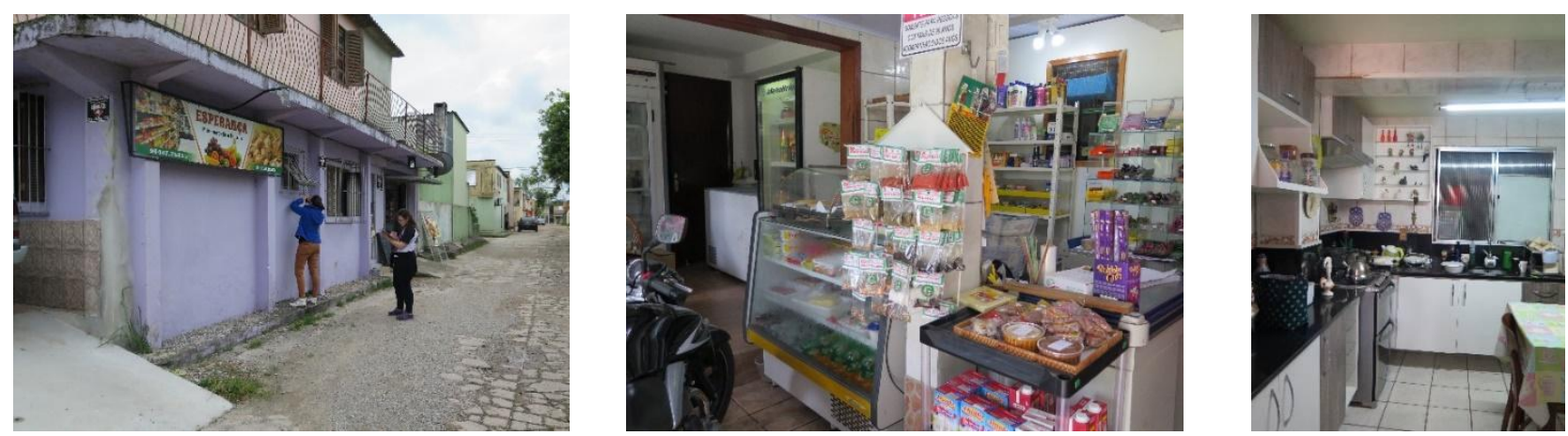

Fig. 9 - Imagens do exterior da unidade de esquina, do balcão comercial e da cozinha residencial ampliada. Fonte: Dos autores, 2018.

Esse caso ilustra a necessidade de considerar usos mistos ou expansibilidade para usos comerciais em novos planos habitacionais e bairros planejados, especialmente em áreas periféricas de maior deslocamento das áreas centrais, diante das necessidades de uso cotidiano. Complementarmente, as atividades comerciais de pequeno porte e o Microempreendedorismo individual são decisivos para a economia no País. O levantamento desenvolvido no bairro, em 2018, apontava para o predomínio de atividades de negócios voltadas para o comércio varejista de mercadorias em geral, com predominância de produtos alimentícios, bebidas e padarias, seguido por atividades de estética e beleza, cabeleireiros, vestuário, brechós, casas lotéricas e serviços de moto-táxi, dentre outros. Em todos os casos do bairro Lindóia, a presença de atividades comerciais se deu de maneira espontânea, ou seja, com acréscimos construtivos e mudança de uso dos cômodos para abrigar as atividades produtivas. 


\section{SÃOPAULO15 17 LISBOA $25 \sim 26$ JUN 2020 \\ Seminário Internacional de \\ Seminario Internacional de Investigação em Urbanismo Investigación en Urbanismo}

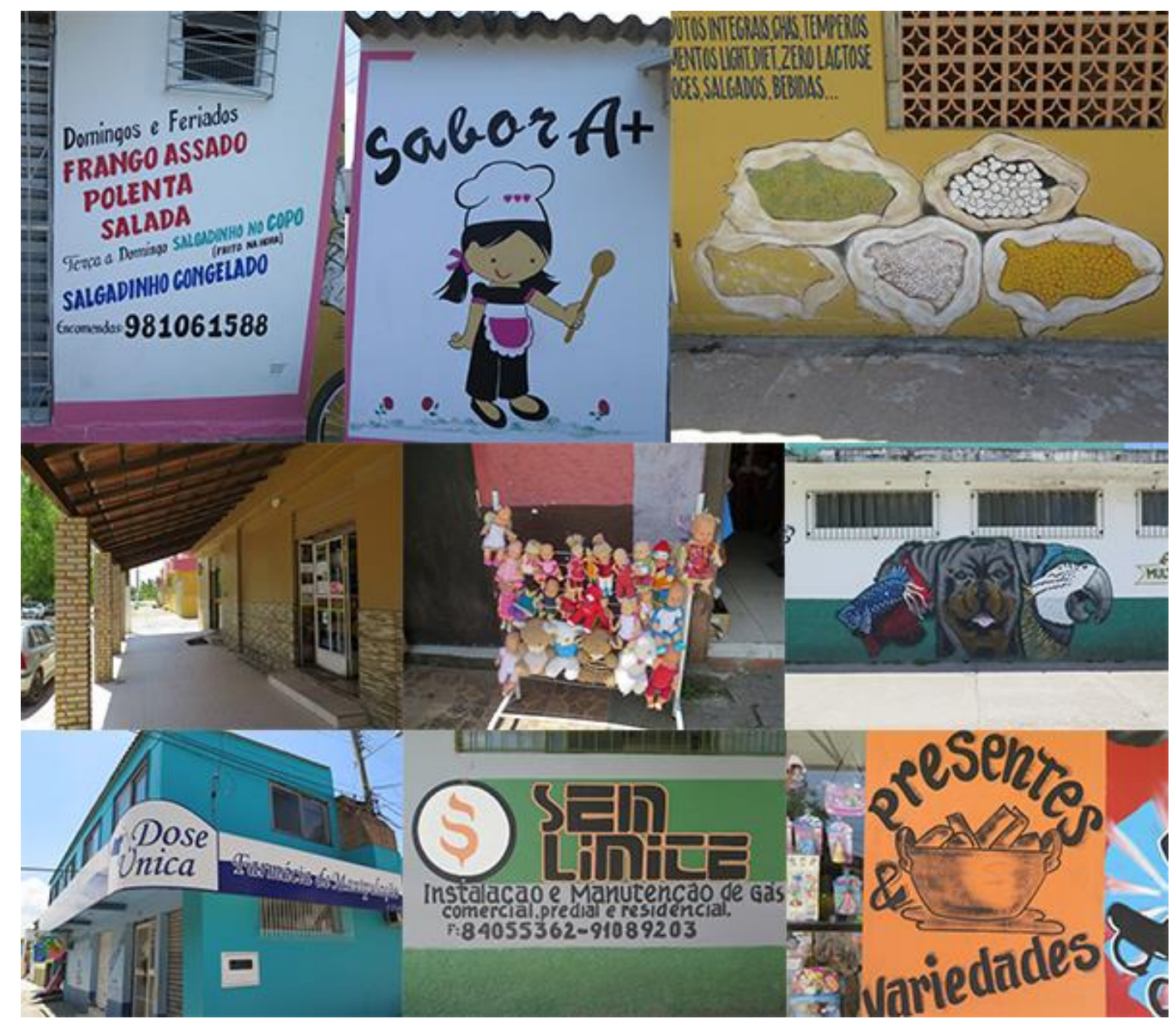

Fig. 10 - Imagens das fachadas de uso comercial e comunicação visual da atividade. Fonte: Dos autores, 2018.

\subsection{Recuo frontal e adição de dormitório principal}

A casa de Raquel é uma das amostras que reflete o padrão de adição de novos dormitórios no afastamento frontal. Contemplada com uma unidade mínima de um dormitório na ocasião da inauguração do Conjunto, Raquel era uma representante da família unipessoal. Sua trajetória modifica-se para uma família monoparental feminina quando nasce o seu filho Lucas. Essa condição, somada à necessidade de ingressar no mercado de trabalho, transforma a vida de ambos. Para conseguir a sua independência financeira, Raquel mantinha uma longa jornada de trabalho no comércio e que, somada ao período de deslocamento entre o Conjunto e o Centro da cidade, implicava longos períodos fora de casa. Por isso, Lucas passa a morar com a avó durante os dias úteis e retorna para a sua casa apenas nos finais de semana. Quando o filho atinge a pré-adolescência Raquel se sente segura em deixá-lo sozinho em casa, retornando definitivamente para o seio familiar. Para proporcionar maior privacidade aos dois, Raquel divide o ambiente único determinado pela sala de estar com um cortinado de tecido, de modo a delimitar o dormitório menor para o filho. O cortinado é logo substituído por um lambri de madeira de boa qualidade presente na residência até hoje. No segundo estágio, inicia-se um processo de reforma na casa com a adição de um novo dormitório para Raquel no recuo 


\section{SÃOPAULO15 17 LISBOA $25 \sim 26$ JUN 2020 \\ Seminário Internacional de Investigação em Urbanismo \\ Seminario Internacional de Investigación en Urbanismo}

frontal da casa, além de construção de uma mureta com grade, do revestimento de piso e dos acabamentos da fachada (Figura 11).

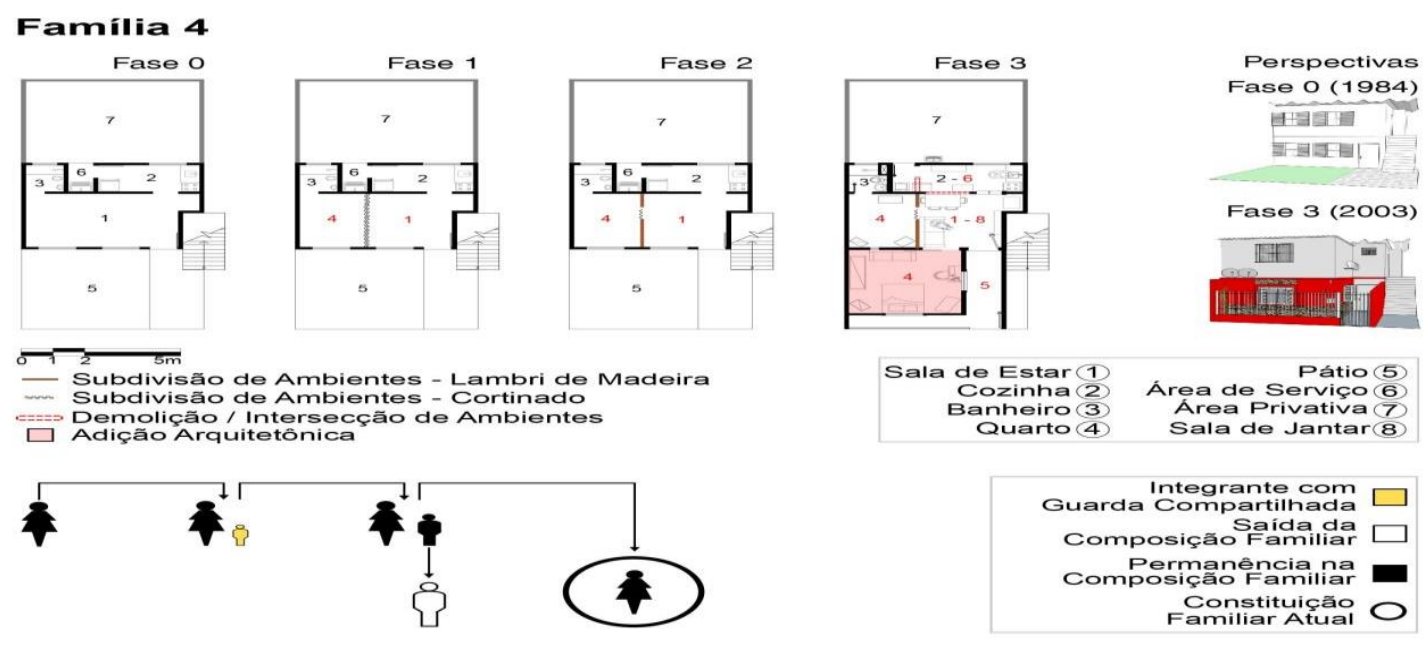

Fig. 11 - Transformação de unidade compacta através da adição frontal de dormitório principal. Fonte: Dos autores, 2018.

A construção foi realizada a passos lentos, conforme a contratante conseguia pagar os profissionais, e constitui a única reforma de adição realizada na unidade, que permanece até os dias atuais. $O$ recuo de fundos agora configura um pátio privativo, devido à pressão imposta pelos limites físicos feitos dos vizinhos das unidades adjacentes, com quartos e outros cômodos de longa permanência orientados para este (Figura 12). Lucas, ao atingir a maioridade, deixa a casa da mãe para constituir a própria família em outra residência do mesmo Conjunto, condição determinante para o suporte emocional da mãe que atingiu a terceira idade e passou a morar sozinha após 40 anos. A unidade, originalmente de $29 \mathrm{~m}^{2}$ atinge a área de $47 \mathrm{~m}^{2} \mathrm{com}$ a adição frontal. Neste momento, o dormitório do filho é um espaço obsoleto, aguardando a expectativa de abrigar sazonalmente o futuro neto.

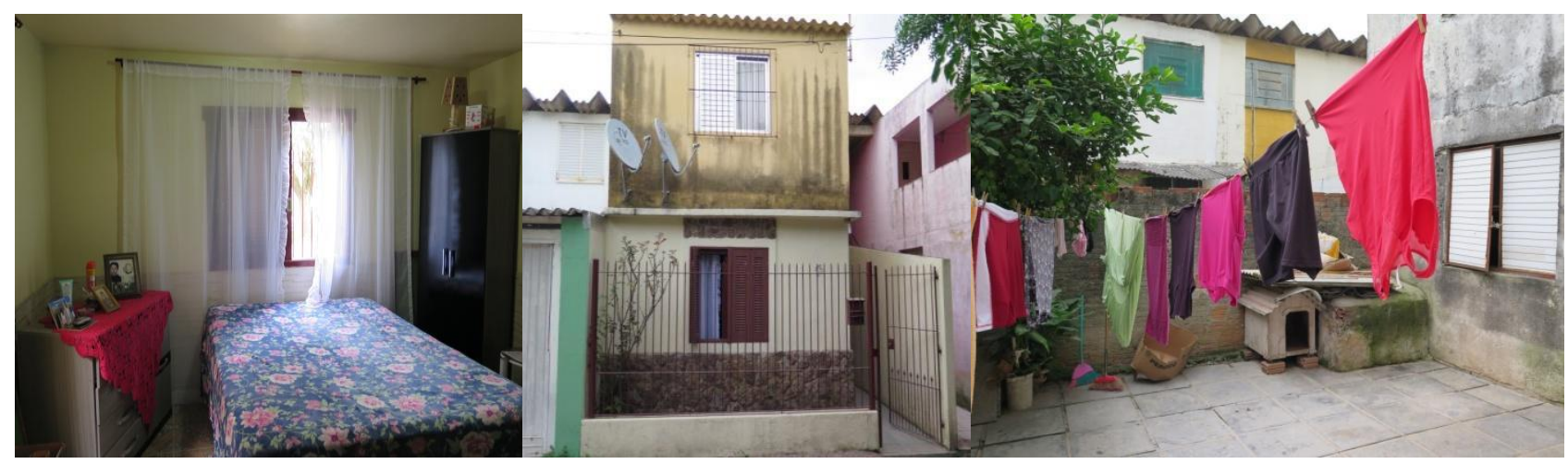

Fig. 12 - Dormitório de Raquel, fachada frontal e pátio de serviço. Fonte: Dos autores, 2018. 


\section{SÃOPAULO15 17 LISBOA $25 \sim 26$ JUN 2020

\subsection{Recuo de fundos - Novos cômodos privativos, lazer, serviços, redução de pátios.}

A amostra a seguir é um exemplar que preserva a integridade do afastamento frontal, a partir de decisões de cunho estético e promove adições de vários cômodos no afastamento de fundos. Marcos é residente do Conjunto desde o seu lançamento e foi contemplado com uma unidade de dois dormitórios à época. Sua família recém constituída nutria a esposa e três filhos pequenos. Com a maturidade, os dois filhos mais velhos constituem a própria família e migram para outro estado em decorrência de melhores oportunidades de trabalho. O núcleo familiar de Marcos se modifica e as atenções se voltam para a filha mais nova do casal, desse modo, ocorre a transformação de um dos dormitórios em sala de estar, e efetua-se uma reforma única de adição no recuo de fundos. Essa reforma é constituída pela adição de três novos cômodos: um quarto exclusivo para a filha caçula; uma sala de estudos para a mesma, estudante universitária pósgraduada dedicada ao concurso público, posição conquistada anos mais tarde; e uma nova área de serviço que viabilizou a ampliação da cozinha antiga e a alteração do layout. A estratégia construtiva que permitiu manter a qualidade mínima de iluminação e ventilação natural foi conquistada pela manutenção do pátio privativo, agora em escala reduzida e quase ao centro da unidade. Com a morte da esposa e a migração da filha mais nova para outro estado, Marcos hoje é um representante típico da família unipessoal na terceira idade (Figura 13).

Este é um dos exemplos mais emblemáticos da incongruência populacional e habitacional existente na COHAB Lindoia. O ciclo familiar, que oscila nos estágios iniciais entre aumentos e retrações, reflete o decréscimo populacional e a redução de membros, condição inversamente proporcional à área construída da unidade. Os cômodos da casa de Marcos, antes utilizados por toda a família e com uma alta especialização de funções, estão obsoletos e servem como depósitos ou como quartos de visitas para as raras visitas dos filhos. Os moveis e objetos são estimados pelo morador como parte da sua história e preservam a identidade e a memória dos seus entes queridos, preenchendo parte da lacuna caracterizada pelo ninho vazio.
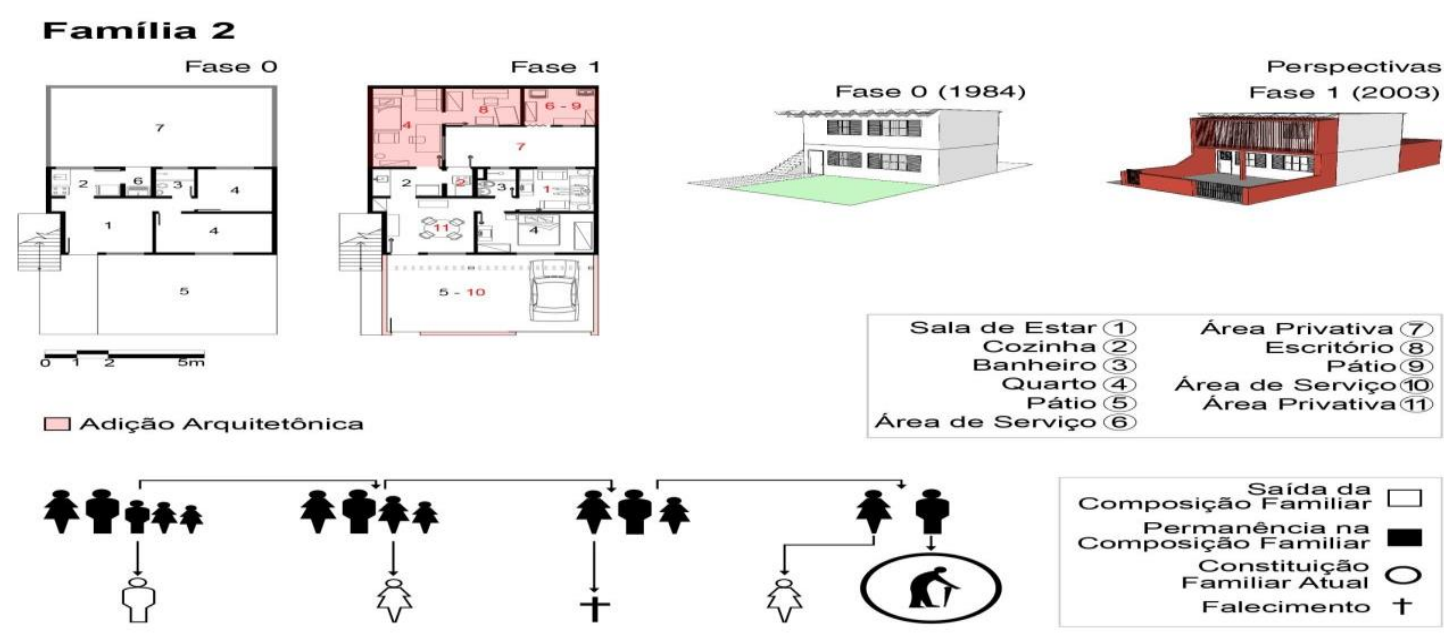

Fig. 13 - Transformação de unidade por adições no recuo de fundos, ao redor de pátio interno. Fonte: Dos autores, 2018. 


\section{SÃOPAULO15 17 LISBOA $25 \sim 26$ JUN 2020}

Seminário Internacional de Investigação em Urbanismo
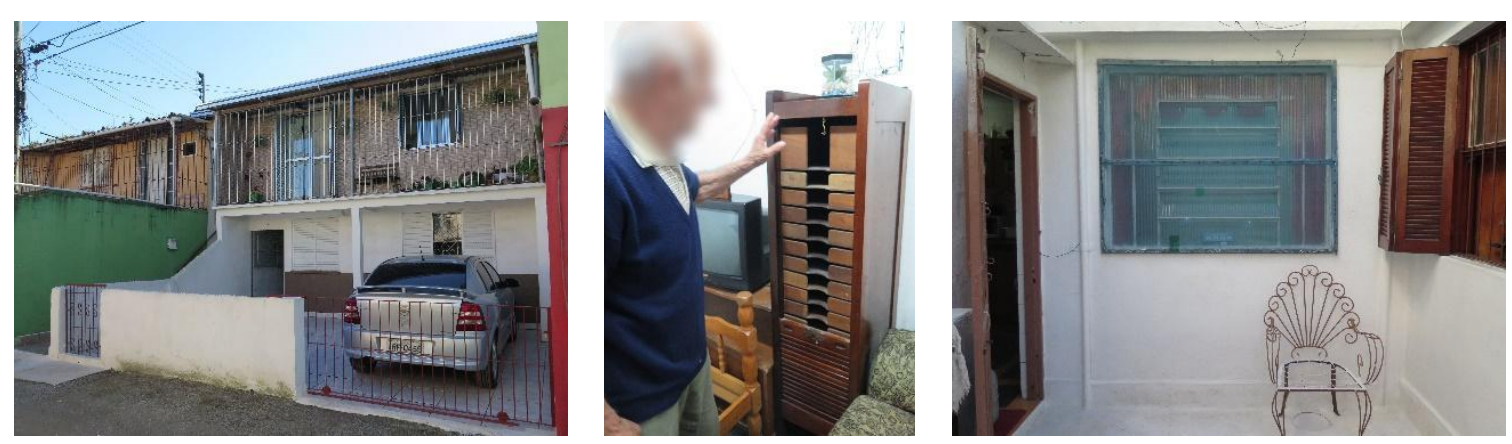

Fig. 14 - Fachada principal, móvel da filha caçula e pátio privativo. Fonte: Dos autores, 2018.

\subsection{Ocupação total do lote - de quitinetes para grandes apartamentos}

Outro padrão recorrente no Conjunto refere-se à supressão integral de ambos os recuos, modificando totalmente as unidades originais e transformando-as em grandes apartamentos. Uma amostra desta situação é a casa de Fernanda, que modifica ligeiramente a configuração interna da unidade original, alterando-se não apenas os usos, mas promovendo adições de novos usos sobre os dois recuos de frente e fundos.

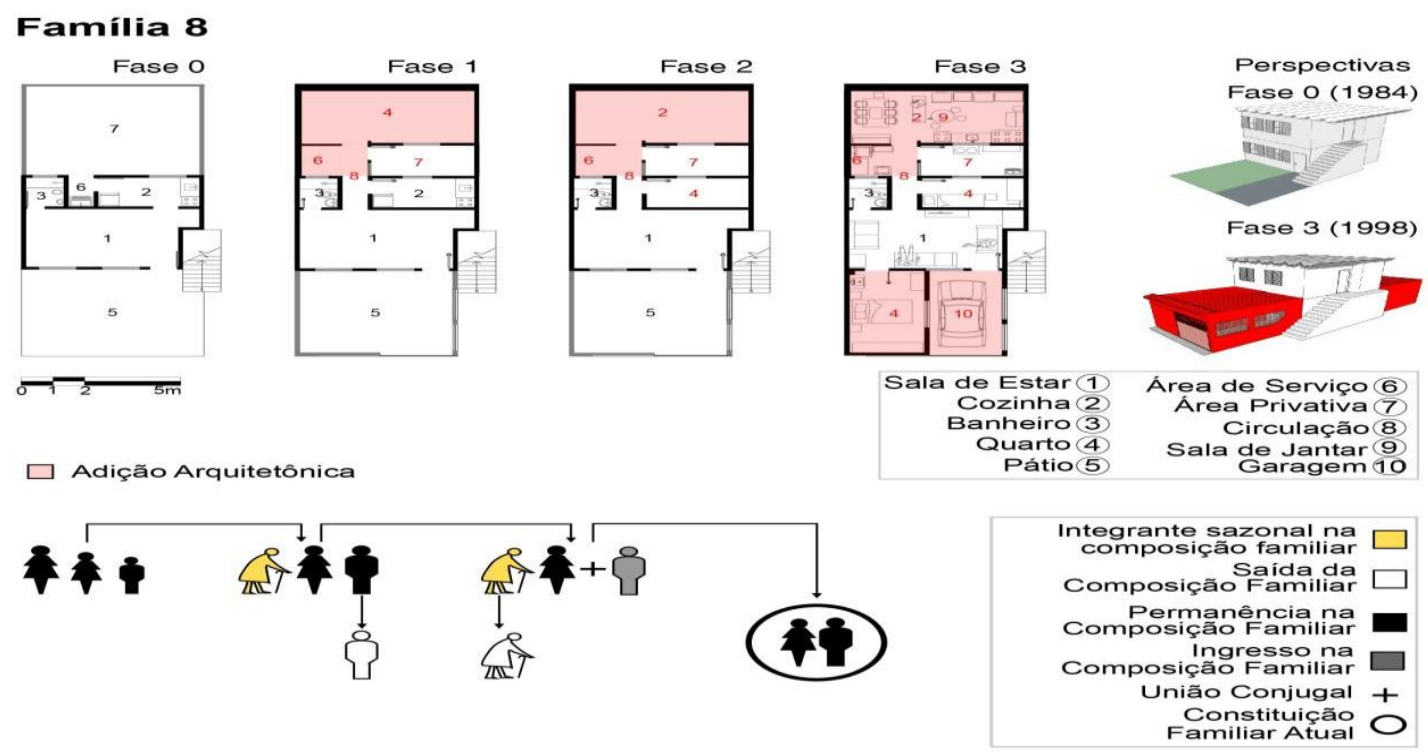

Fig. 15 - Fachada principal, móvel da filha caçula e pátio privativo. Fonte: Dos autores, 2018.

Fernanda é mais uma moradora do estágio inicial do Conjunto, residente de unidade quitinete de $29 \mathrm{~m}^{2}$, com a família composta por três gerações: Fernanda, sua mãe e seu filho. Por questões de privacidade, a sala unitária, em seu estágio inicial, recebe cortinas para fazer a divisão rápida dos quartos. Na fase seguinte é construído um grande dormitório sobre o pátio dos fundos e, posteriormente, esse quarto é transformado em uma grande cozinha com sala de jantar, além de ser implementada uma nova lavanderia e um pátio interno. 


\section{XII $\mathbf{S}$ ÃO PAULO15 17. LISBOA $25 \sim 26$ JUN 2020 \\ Seminário Internacional de \\ Seminario Internacional de Investigação em Urbanismo Investigación en Urbanismo}

A antiga cozinha e a área de serviço transformam-se em um novo dormitório menor e um dormitório adicional para Fernanda é construído no pátio frontal, juntamente com uma garagem coberta que recebe telhas translúcidas para favorecer a iluminação dos ambientes adjacentes. A mãe de Fernanda adquire um novo apartamento, deixando a unidade na COHAB Lindoia para a filha e seu novo companheiro. O último estágio familiar se estabelece com a saída do filho de casa, e agora a casa de $78 \mathrm{~m}^{2}$ é ocupada unicamente pelo casal.

O caso de Fernanda reflete as necessidades e as oportunidades em decorrência do espaço conquistado na unidade. A cozinha passou a ser o coração da casa, com espaço para receber, reunir, preparar refeições (com fogão à lenha, e à gás), além de mesa para refeições formais e correntes (Figura 16). Agora, a expectativa da moradora é ampliar a renda familiar com a venda de biscoitos caseiros e outros produtos culinários.
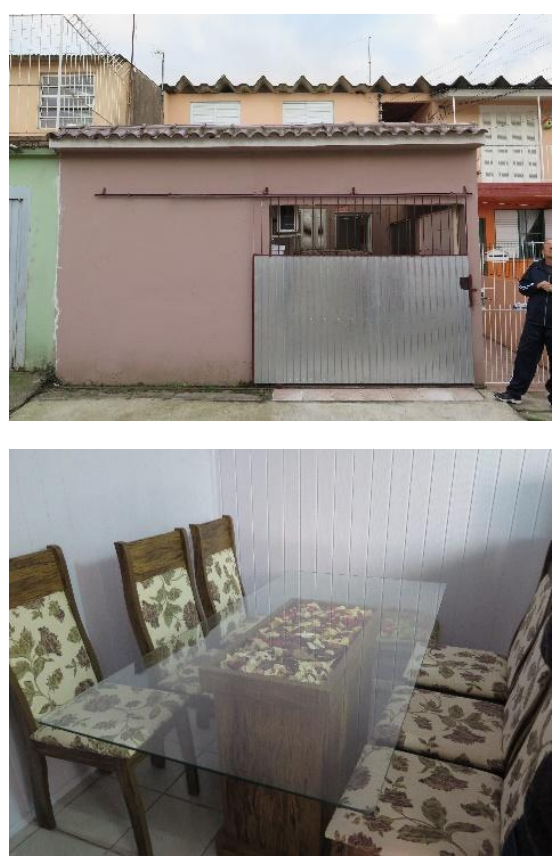
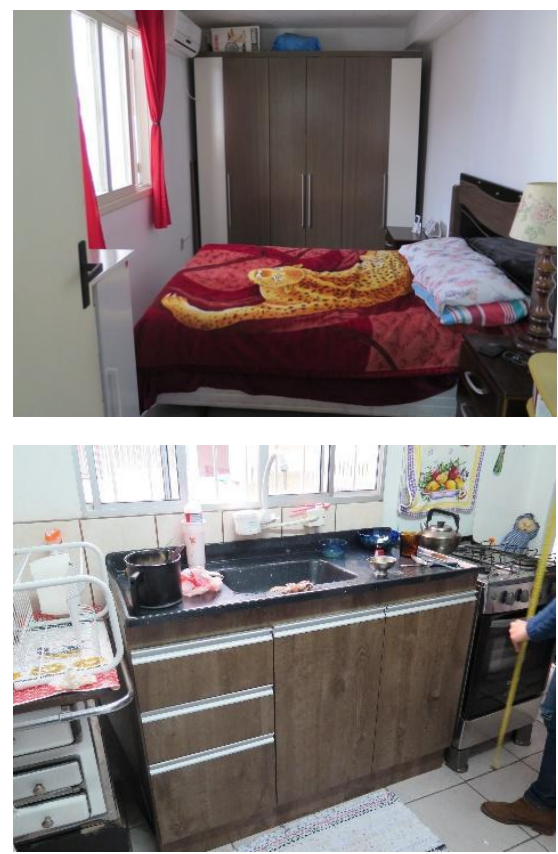
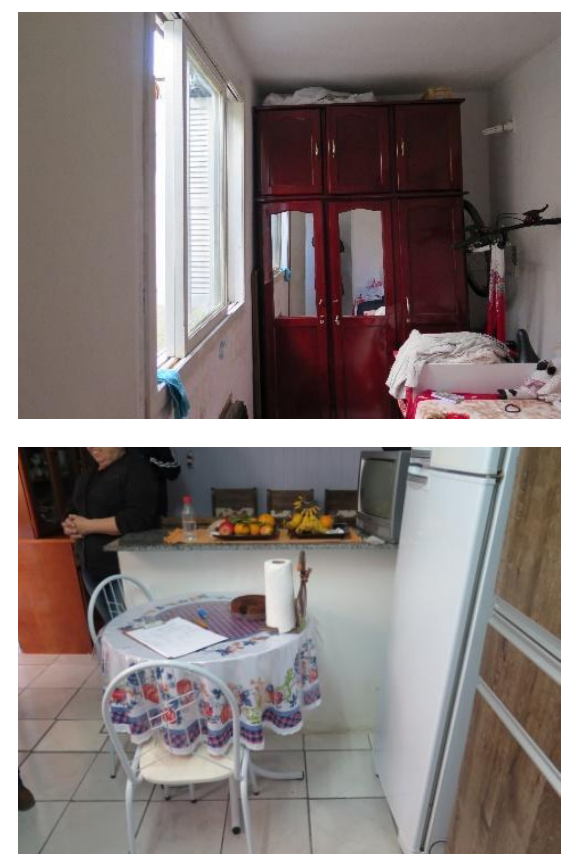

Fig. 16 - Cômodos acrescidos e valorização da cozinha e espaço de refeições. Fonte: Dos autores, 2018.

\subsection{Adição construtiva sobre recuo frontal - dormitórios, garagens cobertas, varandas e dispositivos de proteção e segurança, personalização}

Os recuos frontais foram significativamente modificados por inúmeras adições construtivas, especialmente pelos ocupantes das unidades térreas através de acréscimos que se estendem até o limite imposto pela travessa pedonal. Em sua maioria, os recuos frontais sofreram a adição de dormitórios, garagens cobertas, espaços comerciais, varandas, ou ainda, pela privatização do espaço originalmente coletivo através da elevação de muros e grades, acompanhados muitas vezes da substituição do piso permeável original por pisos de concreto ou revestimentos cerâmicos. A enorme diversidade de tipologias que surgiram a partir do processo de adição progressiva denota uma reconfiguração da paisagem com uma miscelânea de cores, texturas, cheios e vazios. Nos pavimentos superiores, percebe-se o predomínio de terraços e varandas e, 


\section{SÃOPAULO15 17 LISBOA $25 \sim 26$ JUN 2020 \\ Seminário Internacional de \\ Seminario Internacional de Investigação em Urbanismo Investigación en Urbanismo}

para as unidades localizadas nas extremidades das fitas, observa-se o predomínio do prolongamento edificado ou a adição de uma nova unidade ou construção que chega a duplicar a sua área original (Figura 17).

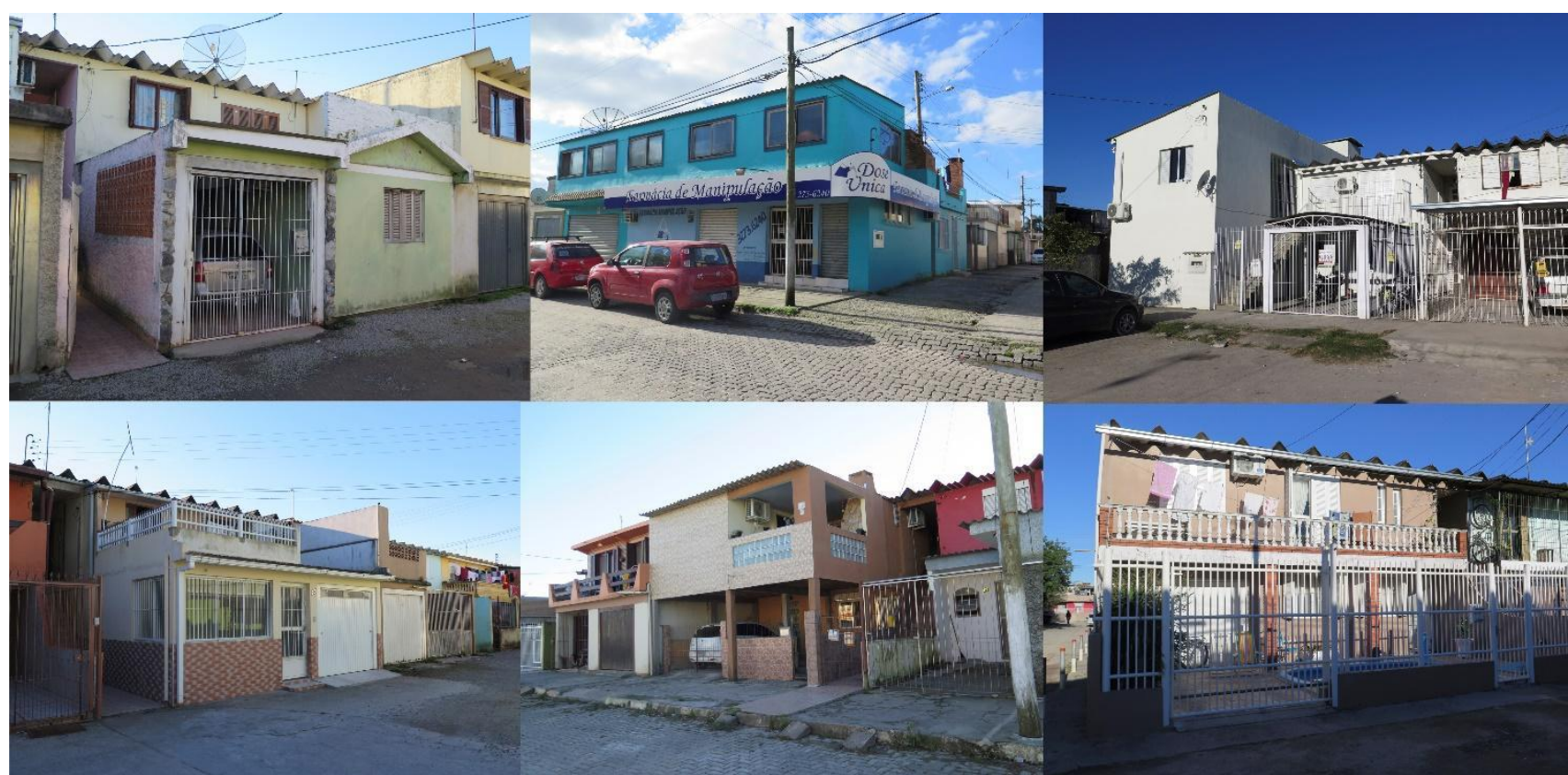

Fig. 17 - Unidades modificadas por adições construtivas e personalização. Fonte: Dos autores, 2018.

Os muros frontais e as grades com portões, presentes em sua maioria nas unidades térreas, predominam em quase todo o bairro, sendo raro presenciar exemplares desprovidos de estratégias de segurança e territorialidade. Nos espaços comerciais predominam portões de aço e quando janelas de cômodos privativos incidem sobre a rua de pedestres, percebe-se a presença de grades de segurança (Figura 18).
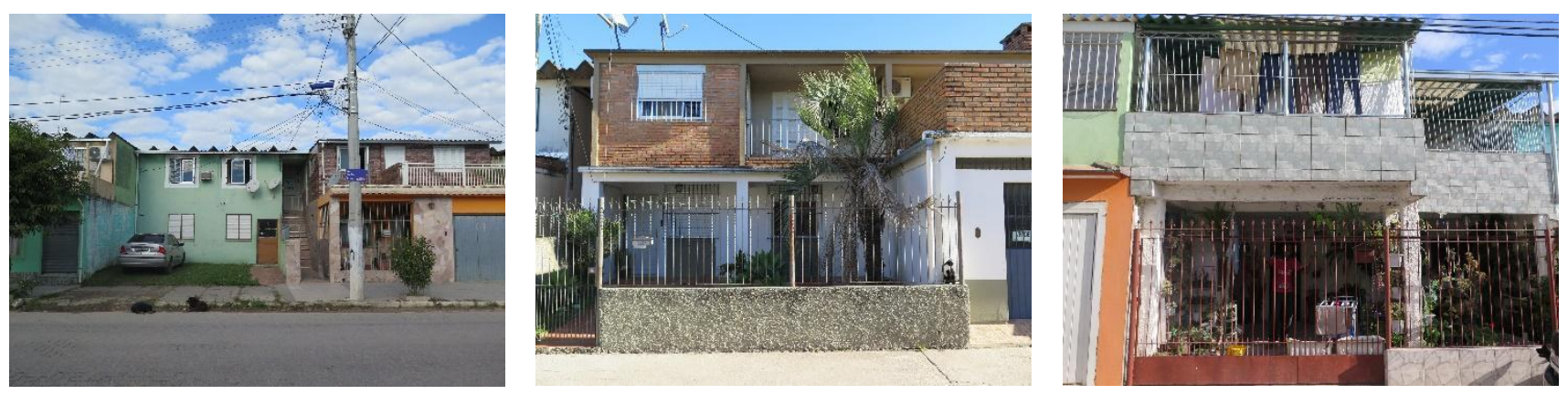

Fig. 18 - À esquerda, exemplar com manutenção do recuo coletivo e demais exemplares com muros e gradis. Fonte: Dos autores, 2018.

\subsection{Unidades Superiores - modificações limitadas pelo sistema construtivo do térreo}

O mapeamento das variações tipológicas e das estratégias construtivas adotadas para o acréscimo identificou a relação de dependência entre as unidades térrea e superior em decorrência do sistema construtivo e dos acordos estabelecidos entre os moradores. Uma vez identificada a presença de adições 


\section{S SÃOPAULO15 17. LISBOA $25 \sim 26$ JUN 2020}

com telhas nas unidades térreas, não é possível promover avanços nos pavimentos superiores. Somente com a adição de estruturas de concreto no térreo e lajes de espera é possível a colaboração entre os moradores do térreo e segundo pavimento. A entrevista realizada com os moradores comprovou que, uma vez acordado entre os moradores a forma de acréscimo, ambos compartilham os custos da obra de forma amigável. Desse modo, há uma relação de dependência dos moradores das unidades superiores em relação ao térreo, uma vez que a cronologia das reformas parte dos moradores das unidades térreas.

O viés do trabalho recai, essencialmente, sobre as formas de expansibilidade da unidade e a sua correlação com as necessidades em distintos estágios do ciclo familiar. Os casos enumerados são apenas uma amostra de como as modificações construtivas caminham em consonância com as formas de implantação das unidades, com acréscimos frente e fundos, e variações nas esquinas. Aponta soluções de acréscimo construtivo para dormitório e estabelecimento comercial, garagem coberta e aberta, sacadas com apoio sobre pilares e fechamento em serralheria e muros no recuo frontal, estratégias enumeradas há mais de 20 anos por Medvedovski (1998).

Em outro trabalho de referência, Brandão (2006) alerta para a relevância do emprego de estratégias de flexibilidade espacial para auxiliar as modificações na fase de uso da habitação. $O$ autor desenvolve um manual técnico para auxiliar projetistas na adaptação e reforma de projetos de HIS e apresenta diretrizes projetuais, e um compendio de plantas mínimas com planejamento para a expansão lateral, frente, fundos, a partir de distintas possiblidades do lote. Convém sinalizar, portanto, que a tipologia "casa em fita" empregada na concepção do COHAB Lindóia apresenta inúmeras restrições diante das possíveis formas de ampliabilidade, sendo recorrente a presença de algumas soluções para minimizar os efeitos nocivos da "casa corredor": pátios internos de transição, cômodos na porção frontal com ocupação de aproximadamente metade da testada do lote, abertura de vãos entre sala-cozinha, áreas cobertas nos fundos do lote com telhado independente, nova cozinha com espaço para refeições, dentre outras.

Em todas as unidades levantadas, nenhum morador recorreu a um profissional de arquitetura, sendo o autor das reformas executadas pelos profissionais contratados. Sob o aspecto das políticas públicas habitacionais, recomenda-se o acompanhamento profissional, de modo a conduzir melhores soluções de conforto térmicolumínico, funcionalidade, privacidade, fluxos e ergonomia. Sob o aspecto coletivo, ocorreram perdas relativas à qualidade do tratamento viário e dos espaços de convívio, especialmente diante da privatização das áreas ajardinadas, com consequente diminuição das relações humanas e inserção do automóvel nos espaços "residuais".

\section{Considerações Finais}

Cada uma das residências analisadas abriga um expoente representativo da família contemporânea brasileira, apresentada à luz de suas modificações e transições que refletem o curso natural da vida e seu rebatimento no espaço doméstico. Foram identificados padrões morfológicos de crescimento que se repetem em outras unidades, bem como um grau de obsolescência quando o último estágio do ciclo familiar se aproxima. O trabalho suscita a reflexão sobre o modelo tipológico imposto pelas COHABs e a necessidade de implementarem-se projetos de habitação evolutiva e flexíveis que respondam às demandas mutantes e contínuas da vida de seus habitantes. Do mesmo modo, abre a discussão acerca de relevância e da urgência em se aplicar a Lei de Assistência Técnica - Lei 11.888/08, de modo a instrumentalizar os moradores para a qualidade das reformas em curso. 


\section{SÃO PAULO15 17. LISBOA $25 \sim 26$ JUN 2020}

\section{Referências}

BARBOSA et. al. Caracterização das condições socioeconômicas, de moradia e saneamento do conjunto habitacional Lindóia segundo os Censos de 1990 e 2010. Anais do Encontro Internacional Cidade, Contemporaneidade e Morfologia Urbana 2018. UFPEL. pp. 536-553. Disponível em: $<$ https://wp.ufpel.edu.br/eiccmu/files/2019/02/capa fapergs-mesclado-compactado.pdf>. Acesso em jan.2020.

BENETTI, Pablo (2012). Habitação social e cidade. Rio de Janeiro: Rio Books's.

BRANDÃO, Douglas Queiroz (2006). Habitação social evolutiva. aspectos construtivos, diretrizes para projetos e proposição de arranjos espaciais flexíveis. Cuiabá: CEFETMT.

GARCÍA-HUIDOBRO, Fernando; TORRITI, Diego Torres; TUGAS, Nicolás. (2008) El tempo construye! Time builds! Barcelona: Gustavo Gili.

IBGE. Censo (2010). Disponível em: < https://censo2010.ibge.gov.br/resultados.html>. Acesso em jan.2020.

MEDVEDOVSKI, Nirce Saffer. (1998). A vida sem condomínio: configuração e serviços públicos urbanos em conjuntos habitacionais de interesse social. Tese de Doutorado. São Paulo: FAUUSP.

NETTO, Vinicius M. (2012) A urbanidade como devir urbano. In: AGUIAR, Douglas; NETTO, Vinicius M. (org.). Urbanidades. Rio de Janeiro: Foglio Digital: Letra e Imagem.

VIEIRA, Sidney Gonçalves. (1997). A fragmentação social do espaço urbano - uma análise da (re) produção do espaço urbano em Pelotas, RS. 1997. 238 f. Dissertação (Mestrado em Planejamento Urbano e Regional), Universidade Federal do Rio Grande do Sul. Porto Alegre. 